\title{
COELIAC DISEASE : A RELATION BETWEEN DIETARY STARCH AND FAT ABSORPTION
}

BY

\author{
WILFRID SHELDON, M.D., F.R.C.P. \\ (From the Hospital for Sick Children, Great Ormond Street, and King's College Hospital)
}

In a previous communication (1948) reasons were given for regarding starch intolerance in children with coeliac disease as perhaps of greater etiological importance than the well known failure to absorb the products of fat digestion. These reasons were (1) coeliac disease usually begins between six months and two or three years of age, and during infancy, at a time when their diet consists of milk, the children who eventually develop this disorder show no indication of what is to come. It is clear that the constituents of milk present no difficulty to the infant who later develops coeliac disease. (2) The principal dietetic change that occurs during the age when coeliac disease becomes manifest consists of a steadily increasing intake of starches. (3) Abdominal distension, which is so constant a characteristic of coeliac children, is not exhibited to any noteworthy degree in infants who for other reasons are intolerant solely of fat, and in coeliac children this feature is much more attributable to fermentation of carbohydrate than to unabsorbed fat.

Assuming that intolerance of starch exerts a primary etiological role in coeliac children, and that failure to absorb fat is a secondary consequence dependent in some way upon mismanagement of starch, it might be possible to improve fat absorption by eliminating starch from the diet, always provided that the failure of fat absorption does not so alter. conditions in the intestine that once this failure has developed it then persists by its own mechanism. It was decided to put this matter to trial by feeding coeliac children on two consecutive diets, both containing an ample portion of fat, the first diet containing starch and the second being free of starch, and to compare the absorption of fat from each diet by means of fat balances. It was soon evident that fat absorption was much improved on a diet free from starch. The investigation was then reversed, beginning with a starch-free diet and later changing to one containing starch; again it was demonstrated that the inclusion of starch in the diet lowered the absorption of fat.
Experiments on these lines have been conducted on fifteen children with coeliac disease, and the results, which are set out in table 1 , form the basis of this communication.

\section{Clinical Cases}

With the possible exception of case 7 , all the children fulfilled the requirements for a diagnosis of coeliac disease. Their illness had started between ten months and three years of age, after a healthy infancy. Failure of appetite, irritability, loss of weight, often to a severe degree, abdominal distension, and the passage of loose, pale, offensive motions were the characteristic features. Analyses of the stool fats showed these to range between 40 and 60 per cent. of the dried stool. In every case tuberculin skin tests were negative, and in those submitted to x-ray examination of the chest and abdomen there was no evidence of tuberculous infection. The oral glucose tolerance curve was flat. The duodenal juice of each child was shown to contain trypsin, lipase, and amylase. The stools were examined for parasitic ova and for cysts of Lamblia with negative results. The exception was case 7 , in whom after several negative examinations, a stool was found to contain Lamblia cysts. By that time she had completed the first half of her dietetic experiment and, as her other symptoms of wasting (at four and a half years she weighed $26 \mathrm{lb}$.), abdominal distension, typical motions, and a flat oral glucose curve were so suggestive of coeliac disease, her experiment was allowed to continue. She was given a course of mepacrine, $0.05 \mathrm{~g}$. twice daily for five days, between her two fat balances, and subsequently evidence of Lamblia infection disappeared. It was thought justifiable to include her results in this series, but were her case withheld the conclusions reached on the remainder would not be affected.

Cases 1 to 7 inclusive were new patients hitherto untreated for coeliac disease. Of these, the condition of nos. $1,3,4,6$, and 7 could be assessed clinically as severe, nos. 2 and 5 as moderate. Cases 8 to 15 inclusive had undergone previous treatment in various hospitals with varying degrees of improvement. Of these, at the time their experiment began, nos. 8 and 14 were still clinically severe, 


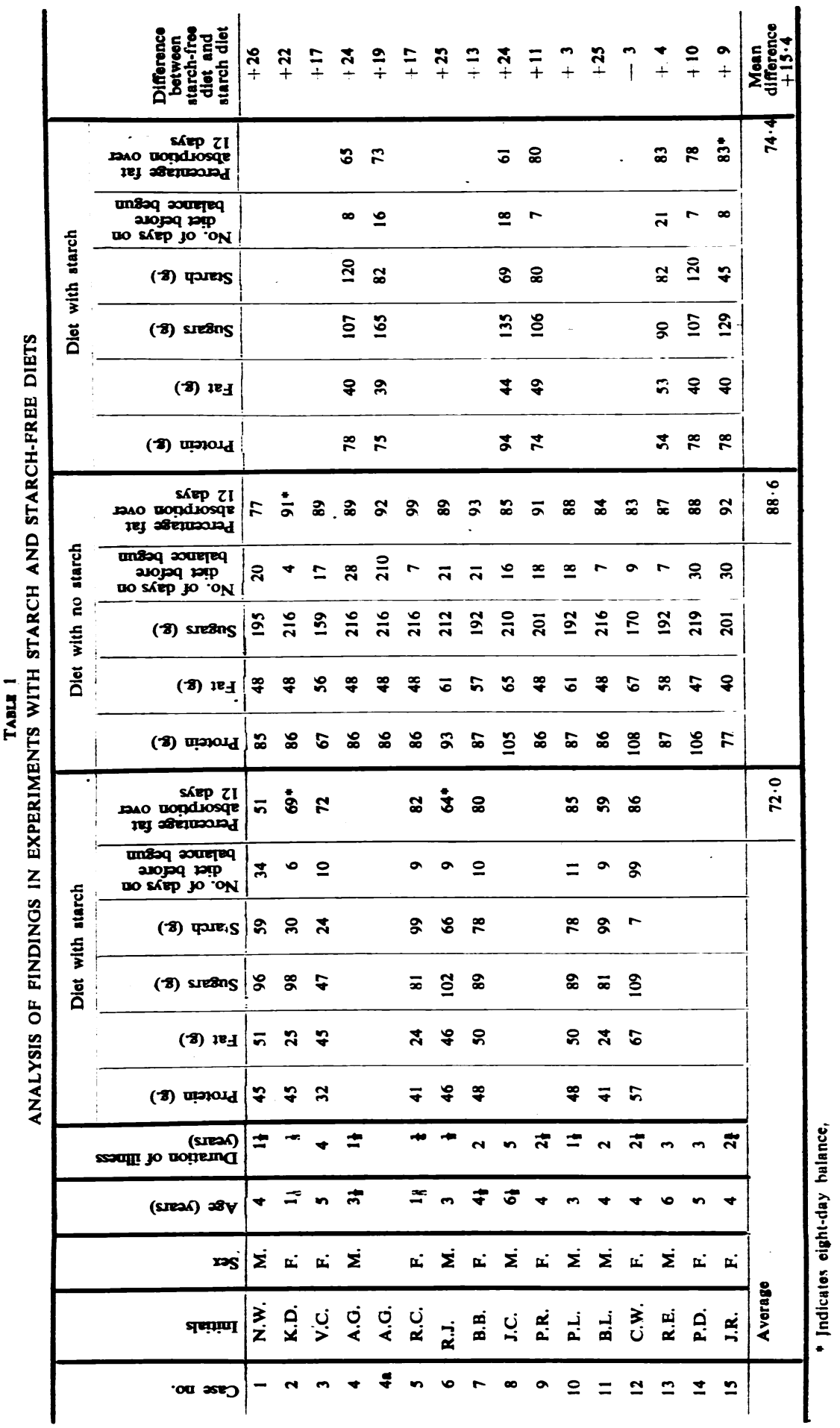


nos. $9,11,12$, and 15 were moderate, and nos. 10 and 13 could be regarded as mild.

Attention must be drawn to cases 4 and $4 a$. These refer to one and the same child. The first experiment was conducted on his admission. He was then put on a starch-free diet, with considerable benefit, over a period of $\mathbf{2 1 0}$ days, and the experiment was then repeated. It was thought that perhaps after so long a period of improvement, during which he had gained $12 \mathrm{lb}$. in weight, the addition of starch might not affect his capacity to absorb fat, but this was not so; his fat absorption fell from a normal figure of 92 per cent. to 73 per cent.

In case 10 the fat absorption on a starch-free diet would probably have been higher had he not had an upper respiratory infection during the middle four days of his twelve-day balance. This was the only occasion on which an infection might have vitiated the fat balance results.

The diets. The starch-containing diet conformed roughly to the ordinary ward diet. Tradition dies hard, and the concept of a low-fat diet for coeliac children had been the custom for so long that a word of praise is due to the dietitians who elaborated for these children diets containing unskimmed milk and virtually a normal amount of fat. The total daily intake of milk was for some children reduced to half a pint or less, drinks of milk being replaced by Prosol made with water. Prosol is a powder having a composition of protein 63 per cent., fat 1 per cent., carbohydrate 26 per cent.

One knows by experience how badly coeliac children tolerate a normal diet unmodified in any way, and the question of whether to start the balance experiments on a starch-containing or a starch-free diet was sometimes decided by the inability of the children to tolerate the former diet. In other children who began with a starch-containing diet, their condition steadily deteriorated, and onily the skill of the nursing staff in persuading the children to take their food enabled this part of the experiment to continue for the required time. From these remarks it will be correctly gathered that of the two diets the one without starch was the better tolerated. Even after a period of improvement on a starch-free diet, in some children the change to a diet containing starch so interfered with health and appetite that the conduction of a twelve-day balance presented considerable difficulty, and in case 16 the change for the worse was so serious that the second balance had to be abandoned. It was eventually carried out three months later after the child's health had been steadily built up on a starch-free diet.

A starch-free diet would have been difficult to produce in a form acceptable to the children without the use of Soya bean flour. This contains considerably more protein and fat than other flours, but is devoid of starch, the carbohydrate being in the form of dextrins. It has a different taste from other flours, and the children often required a few days to become accustomed to it. A recipe of Soya flour
$6 \mathrm{oz}$., margarine $4 \mathrm{oz}$, sugar $4 \mathrm{oz}$, and one egg was used to prepare Soya biscuits, and these not only gave the sense of repletion ordinarily provided by starch, but provided something firm for the children to bite upon in place of bread or toast.

It had originally been hoped that the calorie value of the two diets would be approximately the same, but Soya flour has a higher calorie value than other flours, and this difference is still further enhanced by the recipe for Soya biscuits; consequently the starch-free diet always had a higher calorie content than the diet with starch. For this reason it has been thought necessary to show in table 1 the composition of each child's diets in grammes of protein, fat, sugars (including dextrins), and starch. It will be noted that the starch-free diet contained more protein and sugar and to a less extent more fat than the starch-containing diet.

The daily intake of fat on the starch-free diet averaged $53 \mathrm{~g}$., or $11 \frac{1}{2} \mathrm{oz}$. per week, which may be compared with the standard ration in this country for children of two to five years of $12 \frac{1}{2} \mathrm{oz}$. per week, calculated to include their pint of milk daily, and their weekly ration of bacon, egg, and cheese.

With regard to the size of the diet, this had to be gauged as closely as possible in relation to each child's appetite, so that while the intake should be enough to satisfy, refusal of food or vomiting should be reduced as much as possible, as of course all such rejections had to be measured. A week was often required after the diet had been changed to adjust the intake to the appetite.

As an example of the actual diets, those given to case 9 are set out in table 2 . These have been selected because the starch-free diet contained only 100 calories per day more than the starch-containing diet. The average difference in calories between the two diets was 315 calories.

Technique. Frazer (1947) has stated that a normal human subject on a diet containing $50 \mathrm{~g}$. of fat absorbs 95 per cent. or more of the fat ingested, and that fat absorption may be regarded as defective in all cases absorbing 90 per cent. or less. Fat absorption is known to be defective in tropical sprue, and Black and Fourman (1947), when conducting fat balance investigations in this condition, pointed out that the customary period of four days for a balance test was unreliable because consecutive four-day balances could show considerable variation in the amount of fat absorbed, and they therefore extended the period in their investigations to twelve days. It would seem that in a normal subject a four-day period for a balance test may be sufficiently long, but that when a defect in fat absorption is to be expected a longer period is required. Failure to absorb fat is constantly found in coeliac disease and therefore it was decided to conduct the balances on the coeliac children over twelve-day periods. The procedure adopted was to carry out three consecutive four-day balances, the results being totalled to give a twelve-day balance. 
Tame 2

EXAMPLE OF THE ACTUAL DIETS (CASE 9)

\begin{tabular}{|c|c|c|c|c|c|c|c|}
\hline \multirow{2}{*}{\multicolumn{3}{|c|}{ During the day }} & \multicolumn{3}{|c|}{ Starch-containing } & \multicolumn{2}{|l|}{ Starch-free } \\
\hline & & & $\cdots$ & $\begin{array}{l}\text { Prosol (1 in 8) } \\
\text { Dextri-maltose } \\
\text { Radiostoleum } \\
\text { Ascorbic acid }\end{array}$ & $\begin{array}{l}1 \text { pint } \\
1 \text { oz. } \\
10 \text { drops } \\
50 \text { mg. }\end{array}$ & $\begin{array}{l}\text { Prosol (1 in 8) } \\
\text { Dextri-maltose } \\
\text { Radiostoleum } \\
\text { Ascorbic acid }\end{array}$ & $\begin{array}{l}1 \text { pint } \\
1 \text { oz. } \\
10 \text { drops } \\
50 \text { mg. }\end{array}$ \\
\hline Breatfae & & .. & $\cdots$ & $\begin{array}{l}\text { Prosol } \\
\text { Bread } \\
\text { Butter } \\
1 \text { egg }\end{array}$ & $\begin{array}{l}1 \mathrm{oz} . \\
\mathbf{t} \mathrm{oz} .\end{array}$ & $\begin{array}{l}\text { Prosol } \\
\text { Banana purée } \\
2 \text { Soya biscuits }\end{array}$ & 402. \\
\hline Dinnex . & . & .. & $\cdots$ & $\begin{array}{l}\text { Minced chicken } \\
\text { Potato } \\
\text { Butter } \\
\text { Rice } \\
\text { Milk } \\
\text { Black currant purée } \\
\text { Sugar }\end{array}$ & $\begin{array}{rl}1 & \mathrm{oz} \\
2 \mathrm{oz} \\
1 \\
10 \mathrm{oz} \\
10 \mathrm{gm} \\
5 \mathrm{oz} \\
1 \mathrm{oz} \\
10 \mathrm{~g} .\end{array}$ & $\begin{array}{l}\text { Minced chicken } \\
\text { Tomato purée } \\
\text { Spinach, beetroot, or cauli- } \\
\text { flower purée } \\
\text { Milk } 5 \text { oz } \\
\text { 安 egg } \\
\text { Sugar } 10 \mathrm{~g} . \\
\text { Cooked apple purée } \\
\text { Honey }\end{array}$ & $\begin{array}{r}1 \mathrm{oz} . \\
4 \mathrm{oz} \\
2 \mathrm{oz} \\
\text { coss } \\
\text { custard } \\
4 \mathrm{oz} \\
1 \mathrm{oz}\end{array}$ \\
\hline Tea & .. & .. & .. & $\begin{array}{l}\text { Bread } \\
\text { Butter } \\
\text { Wheaten biscuits } \\
\text { Prosol }\end{array}$ & $\begin{array}{ll}1 & o z \\
1 & o z \\
\frac{1}{2} & o z\end{array}$ & $\begin{array}{l}\text { Prosol } \\
\text { Banana purée } \\
2 \text { Soya biscuits }\end{array}$ & 402 \\
\hline Supper & . & . & .. & $\begin{array}{l}\text { Wheaten biscuits } \\
\text { Prosol }\end{array}$ & $1 \mathrm{oz}$ & $\begin{array}{l}\text { Prosol } \\
\text { Egg custard } \\
\text { Apple purée } \\
\text { Honey } \\
2 \text { Soya biscuits }\end{array}$ & $\begin{array}{ll}5 & \mathrm{oz} \\
4 & \mathrm{oz} \\
1 & \mathrm{oz} .\end{array}$ \\
\hline Cabrie & value & $\cdots$ & $\ldots$ & $1,483 \mathrm{C}$. & & $1,585 \mathrm{C}$. & \\
\hline
\end{tabular}

It has already been pointed out that the condition of the children sometimes made it very difficult, if not impossible, to maintain the balance for as long as twelve days, especially during the phase of the starch-containing diet, and in fact on four occasions the balance had to be discontinued after eight days. The cases in which this occurred are indicated in table 1; apart from them, all the balances in that table refer to a twelve-day period. The performance of balances over such a relatively long period added very considerably to the work of the nursing staff, and made heavy inroads on the working capacity of the laboratories; in fact this latter problem became so serious as to reduce the number of children on whom these investigations could otherwise have been carried out. During the final analysis of results the opportunity has been taken to inquire whether a twelve-day period was really essential and, as will appear later, it would seem that the broad conclusions would have been the same had the period been one of eight days.

The estimation of the total amount of fat in each four-day collection of stools was carried out in the laboratories at Great Ormond Street under the direction of Dr. W. W. Payne, and at King's College Hospital under Professor Gray, and I am deeply indebted to them and their technicians for making this investigation possible. In all cases the estimate of fat was made from the dried stool. Although methods of sampling differed slightly at the two hospitals and at the former carmine was used as a marker, whereas at the latter a high enema was employed for this purpose, the results from the two laboratories were similar. Actually cases 2,11 , and 12 were from King's College Hospital, the remainder from Great Ormond Street and its country branch at Tadworth.

During the period of the balance the daily intake of fat was measured, any food refused or vomited being deducted from the daily intake. The difference between the total intake of fat and the total output in the faeces gave the amount of fat absorbed, and this, expressed as a percentage of the total fat intake, gave the percentage fat absorption.

It was impossible to perform the balances on a strictly consecutive series of cases because no really reliable technique for collecting the whole of the stools from incontinent children could be developed. These children, two or three in number, were therefore not used, but with these exceptions the series was consecutive.

When this investigation began, no information 
was available as to the length of time a child should be on a particular diet before the balance was started. It was soon realized that when carmine was used as a marker it appeared in the stools usually within twenty-four hours, and therefore any alteration in the diet ought to be reflected in the stools within two or three days. But even if dietary starch should interfere with fat absorption, the mechanism of this was not understood, and were it to depend upon a modification of the intestinal flora, it was thought that this might take several days to develop. It was also uncertain whether an alteration in the fat absorption caused by a change of diet would become quickly maximal or be progressively greater the longer the diet was continued; were the latter to be true, the longer the interval before the balance was started the more apparent would be any change in fat absorption. In consequence of these difficulties, no fixed interval has been used. When a change in diet gave rise to deterioration in the child's condition, the balance was started after about a week, but in other children three or four weeks were allowed to elapse. Owing to these differences the interval between a new diet and the ensuing balance has been indicated in table 1. The shortest interval occurred in case 2 , owing to pressure to have the child home, and it is interesting that after only four days on a starch-free diet a radical improvement in fat absorption was manifest.

The absence of controls from normal children is simply explained. If a normal child absorbs at least 90 per cent., and usually 95 per cent. of ingested fat, it would be impossible to register any considerable rise in fat absorption whether the diet contained starch or was starch-free. By carrying out balances on each child while receiving a starch-containing, and a starch-free, diet, each child became its own control, and this was enhanced by varying the order in which the two diets were taken.

It was felt to be desirable that the results should be submitted to statistical analysis, and for this purpose the four-day balances as well as the twelveday totalled results were sent to Dr. Fraser Roberts of the London School of Hygiene and Tropical Medicine, to whom I am greatly indebted for his report. He did not receive the results from case 16, as these were not completed at the time. To quote from his report: - The standard deviation of a four-day estimate of percentage fat absorption during the starch period is $6 \cdot 15$; increasing this to eight days reduces the standard deviation to $4 \cdot 32$; increasing to twelve days reduces it to $3 \cdot 53$. For the starch-free diet the standard deviation for a four-day period is 3.60 ; for eight days 2.55 ; for twelve days $2 \cdot 08$. The accuracy of estimate over four days on the starch-free diet is just about equal to the accuracy of estimate over twelve days on the starch diet. This might suggest using twelve- and four-day periods respectively for the two diets; actually, however, almost exactly the same accuracy is obtained by measuring both over eight days.

- With regard to what period you can most profitably use in the future in order to establish a difference of the order shown by the fifteen children with high significance (chance that it could be due to chance $1 / 100$ ), you would require the following numbers: four-day balance, five children; eight-day balance, four children; twelve-day balance, threefour children (but nearer four than three). To establish that there was such a difference with very high significance (chance that it could be due to chance $1 / 1,000$ ) you would require: four-day balance, seven children; eight-day balance, five or six children (but nearer six than five); twelve-day balance, five children.

-I hope that these figures will help you to weigh the relative advantages of saving laboratory time and doing the work with fewer children. There may be, of course, physiological reasons why duplicate determinations are desirable, but I should imagine that in any event there is a good case for reducing the period from twelve days to eight.

- With regard to the twelve-day balances, the mean difference between the starch-free diet and the starch-containing diet is highly significant and has actually been estimated with fair precision using only fifteen children.'

The greater variation between consecutive fourday balances on a starch-containing diet as compared with a starch-free diet is probably due to the percentage fat absorption on the latter diet more closely approximating to the normal, and not because of any peculiar vice in the starch-containing diet. In other words, the reliability of a single four-day balance becomes greater as the percentage fat absorption moves towards the normal, irrespective of the diet. This is shown in table 3, based on an analysis of the four-day balances.

TABLE 3

ANALYSIS OF THE FOUR-DAY BALANCES

Trelve-day percentage fat absorption

The maximum difference in the groups of three four-day percentage fat absorptions averaged
Between 90 and 99

Between 80 and 89

Between 70 and 79

Between 50 and 69

$3 \cdot 7$
$5 \cdot 7$
$12 \cdot 8$
$10 \cdot 7$

$3 \cdot 7$

$12 \cdot 8$

$10 \cdot 7$
Number of

four-day

estimations 
An isolated faecal fat estimation is of course a less arduous and much shorter investigation than a fat balance. It is therefore appropriate to enquire whether fat absorption can be gauged with any degree of reliability merely from faecal fat estimations. The present investigation offers material for an answer to this question. The figure shows the percentage fat absorption plotted against the percentage of total fat in the dried stool, the figures being obtained from ninety four-day balances. It can be seen that a rough generalization could be made to the effect that the higher the amount of fat in the stools the lower is the fat absorption likely

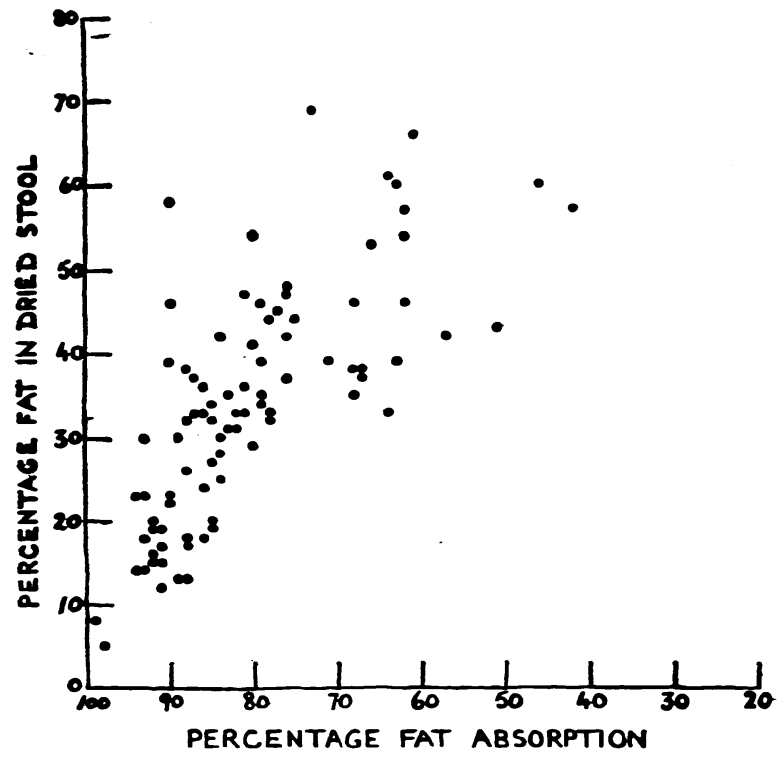

to be, but the plotted points are too widely scattered for this statement to be at all reliable in the interpretation of an individual estimate of faecal fat. A good illustration can be gathered from the five cases in which fat absorption was 90 per cent.; the total fat in the dried stools of these cases ranged between 22 per cent. and 58 per cent. As might be expected, and as is often observed in coeliac children, if the dietary fat is sufficiently rectuced the percentage of fat in the dried stool can be lowered even to single figures, but there is no evidence to show whether this is accompanied by improvement in the absorption of fat. It must be concluded that in coeliac children an isolated estimation of faecal fat does not give any reliable information of the percentage fat absorption.

Effect of a starch-free diet. A study of the effect of a starch-free diet on the health and well-being of coeliac children was not the primary purpose of the enquiry, but the following observations can be made.
Adaption to the diet. Children with a difficult appetite and an antipathy to new tastes took up to a week before they were taking the diet with relish; Soya biscuits, although quite palatable, differ in taste from other starchy foods, and some children needed persuasion to try them. Others with a satisfactory appetite went on to the new diet at once and without difficulty. During the period of adaptation only one child lost weight, and that less than a pound.

Weight. On a starch-free diet every child gained weight steadily. The average increase was at the rate of a pound per fortnight; the two most satisfactory gains were $6 \mathrm{lb}$. in six weeks, and $10 \mathrm{lb}$. in twelve weeks.

Stooks. Prior to the new diet the stools were frequent, loose, and pale. The loose character lasted as a rule about a fortnight, the stools then gradually became formed and remained of this consistency, and their colour became more normal.

Abdominal distension. On the whole this tended to lessen, but not to any great extent, although as the children became plump the distension was less noticeable. On the other hand when a reversion was made to a starchy diet an increase in abdominal distension was soon apparent, and this was accompanied by diminution of appetite, abdominal discomfort, and a very noticeable increase of temperamental irritability.

Temperament. The change for the better in temperament and activity was very striking. Within a few weeks the children were smiling, happy, playful, and actively running about the ward, so much so that one boy practising to be a paratrooper leapt from his bed and unfortunately broke his leg.

\section{- Conclusions}

1. In a group of fifteen children with coeliac disease the withdrawal of starch from the diet was accompanied by a rise in the fat absorption that averaged 15 per cent.

2. The figure of 15 per cent. in this investigation is of high statistical significance.

3. The starch-free diet enabled the children to tolerate virtually a normal fat intake, and led to improvement in weight, the character of the stools, and temperament.

4. A four-day period for a fat balance is too short when fat absorption is defective. Although a twelve-day period was employed in this investigation, an eight-day period would have been sufficient.

5. Estimations of faecal fat alone do not provide a reliable index of the fat absorption. 
In addition to those mentioned in the text, I wish to express my gratitude to the sisters and nursing staff of my ward at The Hospital for Sick Children, Great Ormond Street, the hospital's country branch at Tadworth Court, and King's College Hospital, for their unremitting help and encouragement.
REFERENCES

Black, D. A. K., and Fourman, L. P. R. (1947). Brit. Med. J., 2, 645.

Frazer, A. C. (1947). Ibid., 2, 641.

Sheldon, W. (1948). Ibid., 2, 594. 